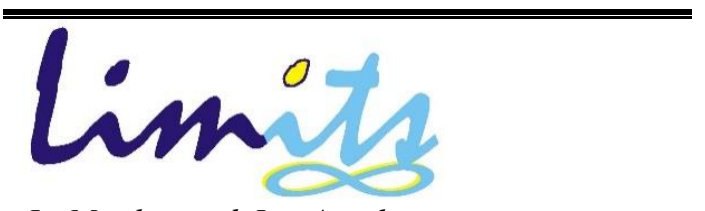

J. Math. and Its Appl.

ISSN: $1829-605 \mathrm{X}$

Vol. 12, No. 1, Mei 2015, 1-11

\title{
OPTIMISASI PEMBENTUKAN SEL DIINTEGRASIKAN DENGAN PENEMPATAN MESIN DAN PENJADWALAN DI DALAM SELULAR MANUFAKTUR MENGGUNAKAN ALGORITMA GENETIKA
}

\author{
Moh Khoiron ${ }^{1}$, Imam Mukhlash ${ }^{2}$, Soetrisno $^{3}$ \\ 1,2,3 Jurusan Matematika, Fakultas Matematika dan Ilmu Pengetahuan Alam \\ Institut Teknologi Sepuluh Nopember (ITS) \\ Jl. Arief Rahman Hakim, Surabaya 60111 \\ 3imamm@matematika.its.ac.id
}

\begin{abstract}
Abstrak
Perindustrian di Indonesia belakangan ini semakin berkembang, hal ini mengantarkannya pada persaingan global, sehingga mendorong banyak perusahaan untuk semakin memperbaiki dan meningkatkan usahanya agar lebih efektif dan efisien. Salah satu yang berdampak signifikan pada keefektifan dan keefesianan suatu perusahaan adalah perencanaan fasilitas. Cellular Manufacturing (CM) adalah salah satu metode yang telah terbukti mampu menambah efisiensi serta fleksibilitas dalam lingkungan produksi manufaktur. Diantara faktor-faktor yang diperlukan dalam selular manufaktur adalah Cell Formation (CF), Group Layout (GL), dan Group Scheduling (GS). Biasanya, tiga faktor ini diselesaikan dalam keadaan terpisah atau diselesaikan secara berurutan. Tugas ahir ini membahas tentang metode untuk penyelesaian CF, GL, GS secara bersamaan. A hierarchical genetic algorithm (HGA) digunakan untuk menyelesaikan permasalahan tersebut.

Kata kunci: Algoritma Genetika; Cellular Manufacturing; Cell Formation (CF); Group Layout (GL); Group Scheduling (GS); Heuristic
\end{abstract}

\section{Pendahuluan}

Perencanaan fasilitas merupakan rancangan dari fasilitas-fasiltas industri yang akan dibangun. Di dunia industri, perencanaan fasilitas dimaksudkan sebagai sarana untuk perbaikan layout fasilitas yang digunakan dalam penanganan material (material handling), penentuan peralatan dalam proses produksi, dan perencanaan fasilitas secara keseluruhan. Ada 2 hal pokok dalam perencanaan fasilitas yaitu, berkaitan dengan perencanaan lokasi 
pabrik (plant location) dan perancangan fasilitas produksi yang meliputi perancangan struktur pabrik, perancangan tata letak fasilitas dan perancangan sistem penanganan material [2].

Penempatan fasilitas di area pabrik, sering disebut juga sebagai Facility Layout Problem (FLP), dikenal memiliki dampak yang signifikan terhadap biaya produksi, proses kerja, penjadwalan dan produktivitas. Sebuah penempatan fasilitas yang baik mampu meningkatkan efisiensi keseluruhan operasi dan dapat mengurangi sampai 50\% jumlah beban usaha[3]. Sebagian besar prosedur dalam pemecahan masalah FLP mengadopsi rumusan masalah yang dikenal sebagai Quadratic Assignment Problem (QAP). Pada QAP, lokasi tiap site ditentukan di depan. Solusi akhir adalah menempatkan fasilitas untuk setiap site sehingga jarak total antara fasilitas diminimalkan. Weights dapat diukur baik oleh indeks adjacency atau dengan volume aliran material antara fasilitas. Itu menunjukkan bahwa QAP merupakan masalah NPlengkap[4]. Sebelumnya telah banyak penelitian yang telah dilakukan untuk menemukan solusi terbaik untuk menyelesaikan masalah FLP. Algoritma genetika adalah salah satu metode yang mampu menemukan solusi optimal.

Meskipun sama-sama menggunakan GA, tapi kebanyakan peneliti berbeda dalam pendekatan permasalahannya, sehingga objective function yang diambil juga berbeda. diantaranya adalah yang dilakukan Koopmans dan Beckmann (1957) yang mendefinisikan FLP sebagai konfigurasi fasilitas, sehingga dapat meminimalkan biaya material handling. Pada kajian yang dilakukan oleh Azadivar dan Wang (2000), didefinisikan bahwa FLP adalah penentuan lokasi relatif dan alokasi untuk beberapa fasilitas pada ruangan yang telah diberikan. Lee dan Lee (2002) mendefinisikan bahwa FLP adalah pengaturan $\mathrm{n}$ fasilitas dengan ukuran yang berbeda di dalam total ruang yang telah ditentukan untuk meminimalkan biaya material handling dan total slack area cost. Shayan dan Chittilappilly (2004) mendefinisikan FLP sebagai masalah optimasi yang membuat layout lebih efisien dengan memperhatikan berbagai interaksi antara fasilitas dan sistem material handling saat merancang tata letak.

Dalam usulan tugas ahir ini, metode penyelesaian masalah FLP akan menggunakan metode Algoritma Genetika (GA) untuk mengintegrasikan cell formation dengan machine layout dan scheduling dalam pendekatan cellular manufacturing. Pertama kali yang dilakukan adalah menganalisa karakteristik workshop dan juga production flow sebuah departemen yang akan diteliti, selanjutnya adalah menformulasikan fungsi tujuan, yang mana dalam penelitian ini fungsi tujuannya adalah meminimalkan makesepan, yang terakhir adalah menyelesaikan permasalahan dengan Algoritma Genetika. Mengingat prinsip GA adalah teknik pencarian stokastik menggunakan prinsip Darwin "survival of the fittest", GA mampu menemukan penempatan posisi fasilitas yang optimal. Sehingga terjadinya proses alur produk yang rapi dan total waktu tempuh part dalam alur produksi diminimalkan. Hal tersebut sangat penting untuk diselesaikan agar dapat menjaga kualitas dan kelancaran produksi. 


\section{Tinjauan Pustaka}

\subsection{Cellular Manufacturing}

Cellular Manufacturing System (CMS) adalah sistem produksi yang mengklasifikasikan parts yang mirip menjadi bagian part families dan mesin yang berkaitan ditempatkan ke dalam sel untuk meningkatkan efektivitas biaya produksi dan fleksibilitas job shop manufaktur.

Pada dasarnya, sistem manufaktur dipecah menjadi beberapa subsistem, dinamakan manufaktur sel. Desain CMS meliputi;

1) Pembentukan Sel(PS) - pengelompokan part yang didasarkan pada fitur desain atau proses yang serupa menjadi part families dan mesin yang terkait ke dalam sel mesin,

2) group layout - meletakkan mesin dalam setiap sel (tata letak intra-sel) dan sel-sel terhadap satu sama lain (tata letak antar-sel),

3) group scheduling - bagian penjadwalan

4) alokasi sumber daya - penugasan alat, sumber daya manusia dan material.

\subsection{Formulasi Masalah}

Untuk membantu lebih memahami masalah dan membangun dasar untuk mengembangkan prosedur heuristik, sebuah model matematika yang komprehensif, yang mempertimbangkan faktor-faktor yang paling penting yang menyangkut CM dan mengintegrasikan CF, GL dan GS, dikembangkan bebarapa variabel dan notasi yang digunakan dalam model

- Pengindekan

i : indek untuk part; $i=1, \ldots, n$

$\mathrm{j}$ : indek untuk mesin; $\mathrm{j}=1, \ldots, m$

$\mathrm{k}$ : indek untuk part; $k=1, \ldots, c$

$o$ : indek untuk operasi; $o=1, \ldots, n_{j}$

$\mathrm{p}$ : indek untuk nomer posisi mesin $\mathrm{p}=1, \ldots, M$

- Parameter

$S p \quad$ set pasang $(\mathrm{i}, \mathrm{j})$ seperti $\quad \mathrm{N}_{\mathrm{i}} \quad$ set operasi yang terjadi $a_{i j}=1$ pada mesin i, $i=$ $1, \ldots, m\left(Z_{j o i}>0, j=\right.$ $\left.1, \ldots, n, o=1, \ldots, n_{j}\right)$

$M$ bilangan sembarang, $\quad \mathrm{t}_{\mathrm{jo}} \quad$ waktu proses mesin untuk bilangan yang besar operasi o dari part $\mathrm{j}, \boldsymbol{o}=$ $\mathbf{1}, \ldots, \boldsymbol{n}_{j}, j=\mathbf{1}, \ldots, n$

$I C_{k} \quad 1$, jika sel k dibentuk; $0, \quad g_{j o} \quad$ waktu selesai operasi o selainnya untuk part j, $h=$ $1, \ldots, n_{j}, \boldsymbol{j}=\mathbf{1}, \ldots, \boldsymbol{n}$

$X_{i k} \quad 1$, jika mesin i berada di sel $\quad g_{[j]}$ waktu selesai operasi $\mathrm{k}$; 0, selainnya o(urutan terahir) dari part $\mathrm{j}, \mathrm{j}=1, \ldots, \mathrm{n}$

$Y_{j k} \quad 1$, jika part j berada di sel $\quad T_{j\left(o o^{\prime}\right)}$ waktu tempuh part $\mathrm{j}$ antara k; 0, selainnya o dan o' 
$M_{i p} \quad p$, mesin i ditaruh pada posisi $p$

$Z_{\text {joi }} \quad 1$, jika operasi o dari part $\mathrm{j}$ diproses pada mesin i; 0 , selainnya

$R_{j} \quad$ set pasang dari operasi[o,o'] untuk part j, dimana operasi o mendahului o', $j=1, \ldots, n$

$$
\left(Z_{j o^{\prime} i^{\prime}}-Z_{j o i}=1\right)
$$

$I_{j}$ set operasi tanpa ada batasan mendahului(operasi yang satu dengan yang lain), $\mathrm{j}=1, \ldots, \mathrm{n}$
$T_{j A} \quad$ waktu tempuh intra-cell part $\mathrm{j}$

$T_{j E} \quad$ waktu tempuh inter-cell part $\mathrm{j}$

$z_{o o^{\prime}} \quad 1$, jika operasi o mendahlui operasi o'; 0 , selain itu. $\forall\left[o, o^{\prime}\right] \in N_{i}, i=1, \ldots, m$

- Fungsi objektif

$\operatorname{Min} \sum_{j=1}^{n} g_{[j]}$

- Kendala

$$
\begin{aligned}
& \sum_{k=1}^{C} X_{i k}=1, \quad i=1, \ldots, m \\
& \sum_{k=1}^{C} Y_{j k}=1, j=1, \ldots, n \\
& \sum_{i=1}^{m} X_{i k} \leq N M \times I C_{k}, \quad k=1, \ldots, c \\
& \sum_{i=1}^{n} Y_{j k} \geq N M \times I C_{k}, \quad k=1, \ldots, c \\
& \sum_{i=1}^{m} M_{i p}=1, \quad p=1, \ldots, M \\
& \sum_{p=1}^{M} M_{i p}=1, \quad i=1, \ldots, m \\
& \sum_{k=1}^{n j} Z_{j o i} X_{i k} Y_{j k} \geq 1, \quad j=1, \ldots, m ; o=1, \ldots, n_{j} \\
& g_{j o^{\prime}}-g_{j^{\prime} o}+M\left(1-z_{o o^{\prime}}\right) \geq t_{j o^{\prime}} \forall\left[o, o^{\prime}\right] \in N_{i}, \quad i=1, \ldots, m \\
& g_{j^{\prime} o}-g_{j o^{\prime}}+M z_{o o^{\prime}} \geq t_{j o}, j \neq j^{\prime} \\
& g_{j o} \geq t_{j o}, \forall j, o \\
& X_{i k}, Y_{j k}, Z_{j o i}=0 \text { atau } 1 \\
& z_{o o^{\prime}}=0 \text { atau } 1 \forall\left[o, o^{\prime}\right] \in N_{i}, i=1, \ldots, m
\end{aligned}
$$




\subsection{Algoritma Genetik}

GA adalah teknik pencarian stokastik menggunakan prinsip-prinsip Darwin yaitu "survival of the fittest" untuk menemukan solusi terbaik. Semakin tinggi fittest-nya, maka semakin tinggi pula kemungkinannya untuk bertahan hidup dan begitu juga sebaliknya. Aspek penting dari GA adalah bahwa, jika diberikan permasalahan yang jelas, GA mampu memberikan solusi yang optimal atau mendekati, bahkan dalam ruang pencarian yang besar dan rumit. GA telah digunakan dalam berbagai bidang praktis termasuk desain, penjadwalan, konfigurasi sistem, manajemen.

GA adalah metode yang mengintegrasikan model stokastik dan pencarian langsung untuk menemukan solusi optimal di dalam waktu komputasi yang terhitung cepat. GA membentuk sebuah populasi solusi yang memenuhi persyaratan dan bertahan dari uji fungsi kelayakan, tapi juga tetap membiarkan solusi yang mempunyai kualitas rendah tetap bertahan agar menghasilkan populasi solusi yang beraneka ragam. Proses ini mampu membuat GA memberikan solusi yang baik juga menghindari Premature Convergence.

Tiap kandidat solusi dalam populasi dikodekan dengan string digit yang disebut kromosom. Offspring atau ketrurunan dihasilkan dari operator probabilistik, yaitu crossover dan mutasi. Kandidat baru(anak) dan lama (orang tua) dibandingkan berdasarkan fungsi kelayakan supaya mengsilkan kandidat yang lebih bagus pada generasi selanjutnya. Pada proses GA ini, karakteristik tiap kandidat solusi diturunkan pada tiap generasai melalui seleksi, crossover dan mutasi.

Rangka GA secara umum ditampilkan dibawah ini.

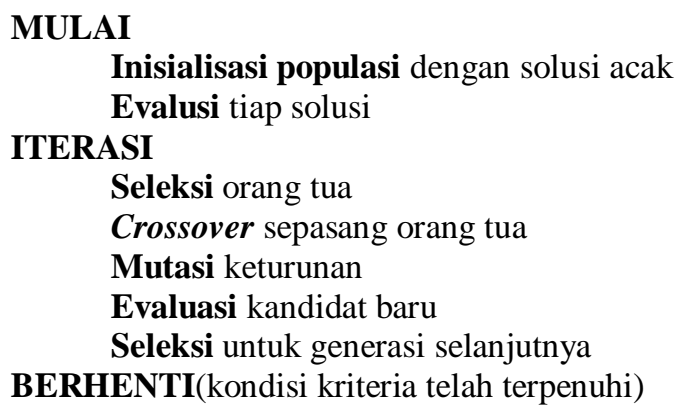

\section{Implementasi}

\subsection{Penyelesaian Pembentukan Sel, Lay-Outing dan Penjadwalan dengan Algoritma Genetika}

Pembentukan Sel (PS) adalah mengelompokkan part yang memiliki kemiripan proses dan desain, serta memasukkan mesin yang bersangkutan ke dalam sel mesin. Pada banyak literatur, dalam pembentukan sel, peneliti mengacu pada analisis aliran produksi untuk membentuk grup part dan mesin yang mempunyai beberapa kriteria, seperti grouping efficiency, grouping 
efficacy, group technology efficiency, dll. PS dimodelkan berdasarkan pada matrik indikator, misal matrik indikator $A=\left[a_{i j}\right] . a_{i j}=1$, jika part diproses pada mesin j, selain itu $a_{i j}=0$. Ide utama dalam Pembentukan Sel adalah meng-cluster semua 'satu' ke dalam tiap sel/diagonal form.

Setelah PS, isu selanjutnya adalah mengurutkan mesin-mesin yang sudah dikelompokkan ke dalam sel-sel tersebut, pada masuk penelitian, fokus utama dalam pengurutan adalah total jarak tempuh proses. Aturan yang digunakan dalam penelitian ini adalah Positional Weight(PB).

Di sisi lain, penjadwalan tergambarkan oleh $p$ pekerjaan dan $m$ mesin akan memiliki $(n !)^{m}$ kemungkin jadwal yang akan terbentuk. Tingkat keberhasilan sebuah jadwa dihitung berdasarkan makespan-nya, yaitu waktu total seluruh proses dikerjakan, menuruti aturan sesuai dengan flow process tiap part.

Dalam penelitian tuga akhir ini, penyelesaian ketiga isu tersebut menggunakan GA berlangsung dalam beberapa tahap; tergambarkan dalam flow chart dibawah.

1. Representasi Kromosom

Untuk setiap penerapan GA, tahap pertama adalah memetakan solusi karakteristik dalam format string kromosom. Setiap kromosom terdiri dari urutan gen tertentu dari alfabet. Alfabet bisa menjadi satu set bilangan biner, bilangan real, bilangan bulat, simbol, atau matriks. Representasi Skema tidak hanya menentukan seberapa efektif masalahnya terstruktur, tetapi juga bagaimana operator genetik dapat digunakan secara efisien.

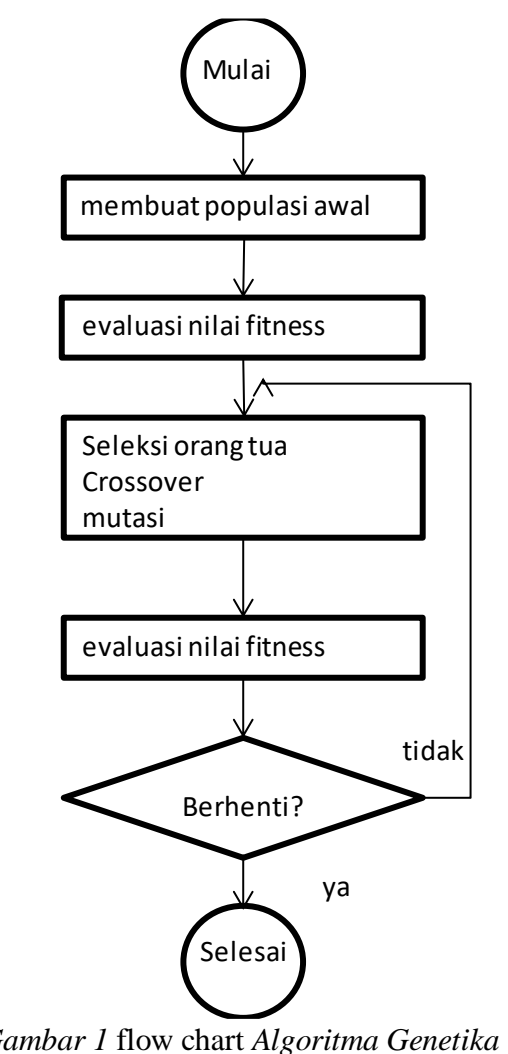


Dalam studi ini, skema yang diusulkan adalah dua-lapis hirarkis. Kromosom terdiri dari dua lapisan gen dengan panjang yang sama. Lapisan pertama digunakan untuk mengkodekan hasil PS dan lapisan kedua digunakan untuk mewakili tata letak dan informasi penjadwalan. Setiap lapisan gen dibagi menjadi dua zona. Zona pertama terdiri dari gen $\mathrm{m}$, terkait dengan mesin dan zona kedua, yang terdiri dari gen $\mathrm{n}$, terkait dengan parts. Oleh karena itu, setiap lapisan memiliki kromosom $\mathrm{m}+\mathrm{n}$ gen.I

\begin{tabular}{|c|c|c|c|c|c|c|c|c|c|}
\hline \multirow[t]{2}{*}{ kromosom } & \multicolumn{9}{|c|}{ mesin } \\
\hline & 1 & 2 & 3 & 4 & 5 & 6 & 7 & $\ldots$ & 72 \\
\hline locus & 1 & 2 & 3 & 4 & 5 & 6 & 7 & $\ldots$ & 72 \\
\hline lapis 1 & 2 & 1 & 1 & 4 & 1 & 2 & 2 & $\ldots$ & 3 \\
\hline lapis 2 & 3 & 72 & 16 & 5 & 1 & 25 & 9 & $\ldots$ & 2 \\
\hline
\end{tabular}

\begin{tabular}{cccccccccc}
\multicolumn{1}{l}{ part } \\
\hline 1 & 2 & 3 & 4 & 5 & 6 & 7 & 8 & $\ldots$ & 14 \\
\hline 73 & 74 & 75 & 76 & 77 & 78 & 79 & 80 & $\ldots$ & 86 \\
1 & 4 & 4 & 1 & 2 & 1 & 2 & 3 & $\ldots$ & 3 \\
5 & 8 & 13 & 14 & 2 & 7 & 1 & 6 & $\ldots$ & 10 \\
\hline
\end{tabular}

Di layer 1, skema direct encoding digunakan, nilai dari setiap gen mewakili nomer sel dimana mesin atau part berada. Misalnya, di contoh menunjukkan bahwa mesin 1 berada pada sel \# 2, mesin 2 berada pada sel \# 1, dan seterusnya, begitu juga untuk tiap part. Part 1 berada pada sel\#1, part berada pada sel\#4, dan seterusnya. Pada layer 2, skema encoding tidak langsung digunakan, dimana nilai dari setiap gen mewakili Posisi Berat (PB) yang mewakili informasi tata letak dan penjadwalan. Besarnya PB ini sendiri sama dengan banyaknya mesin atau part yang diangkat sebagai permasalahan. Semakin besar nilai PB-nya, maka urutannya dalam sel akan didahulukan. Misalnya, PB untuk mesin 1 adalah "3", dan "72" untuk mesin 2, dan seterusnya. PB untuk part 1 adalah "5" dan "8" untuk part 2. Dengan peringkat $\mathrm{PB}$ dari semua mesin, kita bisa menyimpulkan bahwa mesin akan diletakkan dengan urutan pertama untuk layouting adalah mesin 2 dan part 4 untuk scheduling.

2. Inisialisasi Populasi

Tahap kedua GA adalah untuk menghasilkan satu set solusi awal, yang disebut populasi. banyaknya solusi awal yang dimasukkan dalam populasi disebut population size. Solusi awal bisa didapat dengan meng-generate secara acak atau mengkombinasikan antara generate secara acak dan solusi heuristik. Menentukan ukuran populasi yang tepat adalah keputusan yang penting dalam GA. Jika size yang dipilih terlalu kecil, tidak mungkin bisa mendapatkan solusi yang baik. Sebaliknya, jika size tersebut terlalu besar, CPU membutuhkan waktu yang lama untuk menemukan solusi yang baik. Inisialisasi populasi yang diberikan dalam penelitian TA ini adalah 40 .

3. Fitness Function

Fitness Funtion digunakan untuk mengevaluasi dan menentukan apakah suatu kromosom akan bertahan dan digunakan untuk mereproduksi kromosom baru, yang biasa disebut offspring. Fitness Function ini digunakan untuk menghitung nilai fitness setiap kromosom. Nilai fitness 
tidak memerlukan suatu nilai absolut tetapi yang digunakan adalah nilai relatif terhadap populasi tertentu. Kromosom mendapat peringkat sesuai dengan nilai fitness-nya. Pada Tugas Akhir ini, penelitian berfokus pada pencarian makespan terpendek. Dengan memisalkan $g(x)$ adalah fungsi tujuannya, $C_{\max }$ didefinisikan sebagai boundary makespan yang diharapkan dan $f(x)$ adalah fungsi fitness-nya didapatkan model matematika;

$f(x)= \begin{cases}C_{\text {max }_{-} 0}-g(x) & \text { when } g(x)<C_{\max } \\ 0 & \text { selainnya }\end{cases}$

Ada beberapa cara untuk menentukan $C_{\max }$. Bisa saja diambil dari nilai terbesar $g(x)$ sejauh ini atau bisa dari nilai terbesar populasi saat ini.

4. Prosedur Seleksi

Tujuan dari prosedur seleksi adalah untuk memberikan kepada kandidat solusi yang 'terlayak' mempunyai kemungkinan yang lebih besar untuk terpilih menghasilkan keturunan, pada penelitian tugas ahir ini prosedur seleksi yang digunakan adalah Roulette Wheel

5. Operator Genetika

a. Kawin Silang

Reproduksi dilakukan dengan menggunakan operator kawin silang(crossover) yang dilakukan pada orang tua terpilih untuk menghasilkan anak(offspring). Crossover menggabungkan informasi dari dua orang tua tersebut, sehingga kedua anak memiliki kemiripan dari tiap orang tua. Dalam penelitian ini digunakan crossover dengan menggunakan one-point crossover dan partially matched crossover(PMX). Dengan probabilitas crossover-nya adalah 0.65.

b. Mutasi

Operasi mutasi diterapkan pada segmen kedua untuk anak ke-2 yang dihasilkan dari operasi crossover, kemungkinan terjadinya biasanya ditentukan sangat kecil. Mutasi dapat menyebabkan perubahan nilai gen secara acak. Probabilitas mutasi pada penelitian Tugas Akhir ini adalah 0.1.

6. Stopping Criteria

Stopping Criteria digunakan untuk menghentikan proses, di penelitian ini stopping criteria yang digunakan adalah banyaknya generasi yang sudah ditentukan sebelumnya. Maksimal generasi yang digunakan adalah 70 .

\section{Pengujian Sistem dan Hasil}

Pengujian sistem dilakukan dengan tujuan mengevaluasi apakah penerapan suatu algoritma memenuhi kondisi yang telah ditetapkan atau tidak. Pada penelitian kali ini, data uji yang digunakan adalah data TA dari penelitian sebelumnya [8], banyaknya mesin adalah 72 dan banyaknya part adalah 14 jenis., dan data yang di ambil dan di manipulasi dari jurnal, dengan jumlah mesin adalah 7 dan part adalah 14 .

Nilai parameter yang digunakan untuk implementasi GA adalah

1. Jumlah sel: 4

2. Ukuran populasi: 40 
3. probabilitas crossover: 0.65

4. probabilitas mutasi: 0.1

5. Max Generasi: 70

Dari pengembangan perangkat lunak dan permasalahan yang diangkat, dihasilkan solusi untuk masing-masing data sebagai berikut:

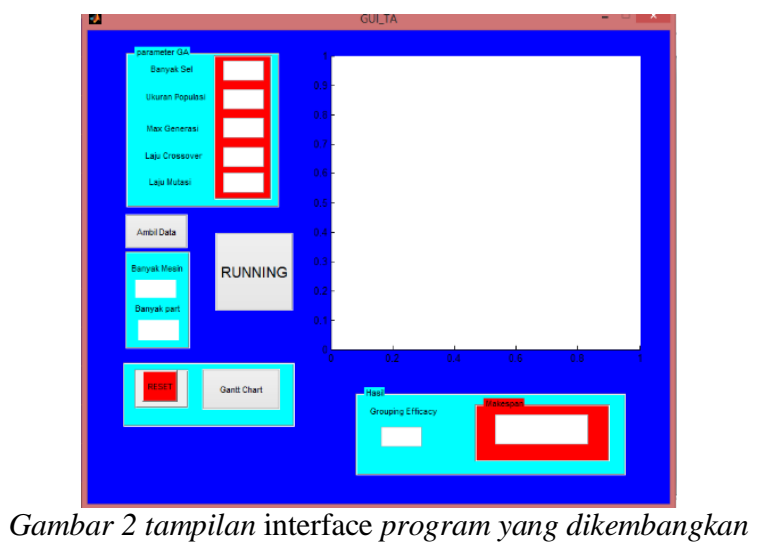

1. Data Jurnal

Pada data jurnal, fungsi fitness mulai stagnan pada generasi kuranf dari 20, ini dikarenakan ruang lingkup permasalahan masih pada lingkup yang kecil. Untuk lebih jelasnya, hasil untuk solusi data jurnal ditampilkan pada gambar dibawah.

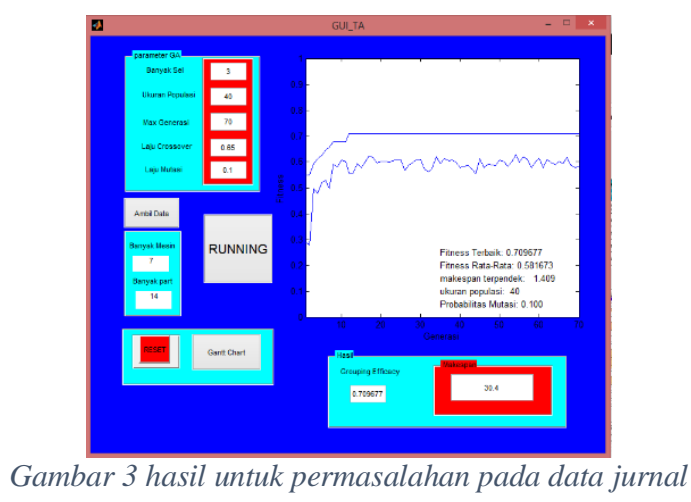

Dan tampilan untuk penjadwalan, ditampilkan pada table Gantt chart dibawah. Setiap warna mewakili masing-masing part 


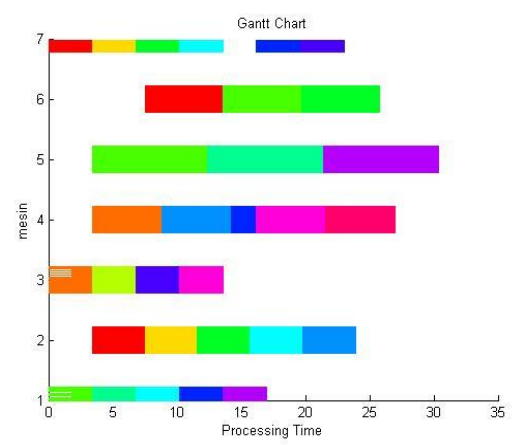

Gambar 4 Gantt chart untuk penjadwalan pada data jurnal

\section{Data TA}

Pada data TA, fungsi fitness terus menanjak sampai dan mulai stagnan ketika mendekati pada generasi terahir, ini dikarenakan ruang lingkup permasalahan termasuk pada lingkup yang besar. Untuk lebih jelasnya, hasil untuk solusi data jurnal ditampilkan pada gambar dibawah.

\section{Kesimpulan}

Berdasarkan keseluruhan hasil analisis diperoleh kesimpulan sebagai berikut:

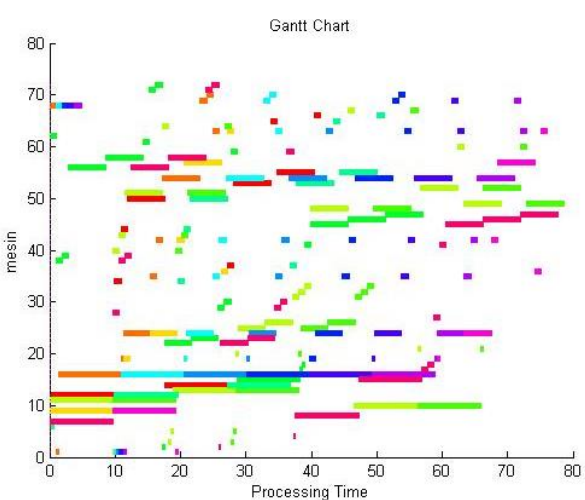

Gambar 5 Gantt chart untuk penjadwalan pada data jurnal

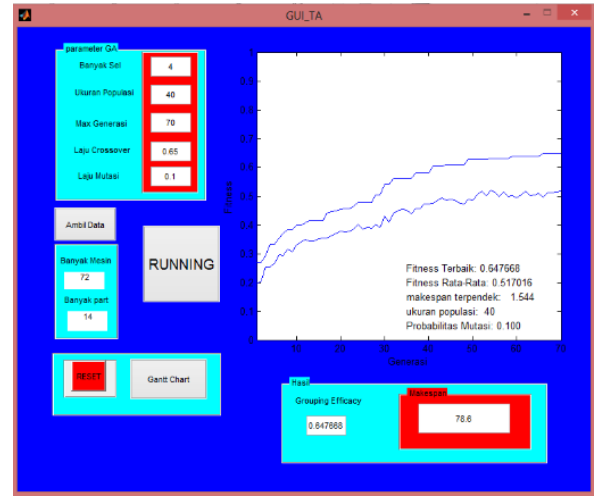

Gambar 6 hasil untuk permasalahan pada data TA 


\section{Daftar Pustaka}

[1] Purnomo, H., Kusumadewi, S. Aplikasi Algoritma Genetikav Untuk Penentuan Tata Letak Mesin. Yogyakarta. Universitas Islam Indonesia.

[2] Apple, JM. Tata Letak Pabrik dan Pemindahan Bahan. Bandung: ITB. 1990.

[3] Drira, A., Pierreval, H., Hajri-Gabouj, S.2007. Facility layout problems: A survey. Annual Reviews in Control, Volume 31, Issue 2, Pages 255267.

[4] Tarn, K.Y.1991.Genetic algorithms, function optimization, and facility layout design. European Journal of Operational Research, Volume 63, Issue 2, Pages 322-346.

[5] Mahdavi, I, Paydar, M.M., Solimampur, M., Heidarzade, A. 2008. Genetic Algorithm Approach for Solving a Cell Formation Problem in Cellular Manufacturing. Expert Systems with Applications, Volume 36, Issue 3, Part 2, Pages 6598-6604

[6] Wu, X., Chu, C. H., Wang, Y., Yan, W.2007. A genetic algorithm for cellular manufacturing design and layout. European Journal of Operational Research, Volume 181, Issue 1, Pages 156-167

[7] Wu, X, Chu, C., Wang, Y., Yue, D.2007.Genetic algorithms for integrating cell formation with machine layout and scheduling. Computers \& Industrial Engineering, Volume 53, Issue 2, Pages 277-289.

[8] Shururi, A. 2008.Optimisasi Tata Letak Fasilitas Dalam Sistem manufacturing Cellular Dengan Menggunakan Pendekatan Genetic Algorithm. Tugas Akhir Teknik Industri FTI ITS. 